\title{
Evaluation of Pre-Mix Fungicide, Fluxapyroxad and Pyraclostrobin 500 SC against Powdery Mildew (Oidium mangiferae) Disease of Mango
}

\author{
M.R. Ravikumar ${ }^{1 *}$, Vithal Navi $^{2}$ and Yashaswini Sharma ${ }^{3}$ \\ ${ }^{1}$ Department of Plant Pathology, ${ }^{3}$ Department of Horticulture, College of Agriculture, \\ Hanumanamatti, Haveri, Karnataka-581 115, India \\ ${ }^{2}$ Department of Agri. Microbiology, College of Agriculture, Dharwad, \\ Karnataka-581 115, India \\ *Corresponding author
}

\section{A B S T R A C T}

Mango (Mangifera indica L.) is one of the best fruit in the world market affected powdery mildew disease which infects panicles, fruits and leaves causing up to 90 per cent crop loss. Hence, an investigation was initiated to study the bio-efficacy of different standard and new fungicides against powdery mildew disease. The experiment was conducted at Sirsi, Uttara Kannada District, Karnataka, India during 2012-14. Pre-mixture of Fluxapyroxad $250 \mathrm{~g} / \mathrm{l}+$ Pyraclostrobin $250 \mathrm{~g} / \mathrm{l} 500 \mathrm{SC}$ is a new fungicide combination effective against fungi in pome and stone fruits. Eight treatments were imposed viz., Fluxapyroxad 250g/l +Pyraclostrobin 250g/l 500 SC @ 1ml/l, Fluxapyroxad 250g/l +Pyraclostrobin 250g/l @ $1.5 \mathrm{ml} / \mathrm{l}$, Fluxapyroxad 250 g/l +Pyraclostrobin 250g/l @ $2 \mathrm{ml} / \mathrm{l}$, Pyraclostrobin 20 WG @ 5 ml/l, Fluxapyroxad @ 3ml/l, Flusilazole $40 \%$ EC @ 0.75 ml/l, Hexaconazole 5\% SC @ $5 \mathrm{ml} / \mathrm{l}$ along with one untreated Control. Two sprays were taken up at 20 days interval during flowering stage. Among the different treatments, Fluxapyroxad 250g/l +Pyraclostrobin 250g/l 500 SC @ 2 ml/L of water recorded significantly lower per cent disease index of powdery mildew on leaves, inflorescence and fruits $(18.00,16.60$ and 17.08 , respectively) than control $(54.73,52.80$ and 53.33 per cent disease index on leaves, inflorescence and fruits, respectively). The same treatment recorded maximum productivity (30.60 t/ha) as compared to control $(15.00 \mathrm{t} / \mathrm{ha})$. There were no visual symptoms of phyto-toxicty noticed in terms of leaf tips and surface injury, wilting, necrosis, epinasty and hyponasty on mango crop by Fluxapyroxad 250g/1 +Pyraclostrobin $250 \mathrm{~g} / 1500 \mathrm{SC}$ treatment even at $4 \mathrm{ml} / \mathrm{l}$ concentration.

\section{Introduction}

Mango (Mangifera indica L.) is one of the most popular juicy stone fruit belonging to the family Anacardiaceae. It is cultivated in frostfree tropical and warmer subtropical climates recognized as king of fruits. It is one of the best fruit in the world market because of its excellent flavor, attractive fragrance, beautiful colour, delicious taste and nutritious value. India stands first in global mango production $(52 \%)$. However, the productivity of mango is 
affected by various diseases. Powdery mildew is the primary cause of poor fruit set and yield in mango. Worldwide, mango powdery mildew is a sporadic, infects panicles, fruits and leaves causing up to 90 per cent crop loss (Nelson, 2008).

The fungus Oidium mangiferae Berthet, causing powdery mildew of mango, is widely distributed throughout the tropics. Wet, humid, warm weather conditions favor powdery mildew infections in the field (Khalid and Alam, 2000). Chemical control has been the most effective method adopted by farmers to protect their crops from fungal pathogens. The pathogens have started developing resistance against the conventionally used fungicides recommended to the farmers. Second generation fungicides have proved as a new ray of hope in better management of diseases under field conditions. Pyraclostrobin is one an efficient fungicide which could control both powdery mildew and anthracnose disease together. It belongs to the strobilurins, a recently introduced group of agrochemical fungicides (Margot et al., 1998). Fluxapyroxad is a succinate dehydrogenase inhibitor and is a new active ingredient with pyraclostrobin labeled as Merivon for use in stone and pome fruits against common leaf spot, powdery mildew and anthracnose (Schilder, 2015). Hence, an investigation was initiated to study the bio-efficacy of pre-mix fungicide, Fluxapyroxad and Pyraclostrobin 500 SC along with different standard fungicides against powdery mildew disease of mango.

\section{Materials and Methods}

The experiment was conducted at Sirsi, Uttara Kannada District, Karnataka, India during 2012-14 with eight treatments of different fungicides, viz., Fluxapyroxad 250g/l +Pyraclostrobin 250g/1 500 SC @ 1 ml/l, Fluxapyroxad 250g/l +Pyraclostrobin 250g/l
@ $\quad 1.5 \quad \mathrm{ml} / \mathrm{l}, \quad$ Fluxapyroxad $250 \quad \mathrm{~g} / \mathrm{l}$ +Pyraclostrobin $250 \quad \mathrm{~g} / \mathrm{l} \quad \mathrm{Q} \quad 2 \quad \mathrm{ml} / \mathrm{l}$, Pyraclostrobin 20 WG @ 5ml/1, Fluxapyroxad @ 3 ml/l, Flusilazole 40 \% EC @ 0.75 ml/l, Hexaconazole 5\% SC @ $5 \mathrm{ml} / \mathrm{l}$ along with one untreated Control. 10 years old Alphonso mango plantations of 1000 square meter area was selected for each treatment.

Two sprays were taken up at 20 days interval during flowering stage (in the month of January). The experiment was laid out in Randomized Block Design (RBD) with four replications. The observations on powdery mildew disease were recorded before and after each spray. Observations on anthracnose disease were recorded seven days after the first spray and the productivity of the plantation was also recorded. Ten plants were examined randomly and scored for disease severity by following 0-5 scale. The details of scales are as shown below.

0 - No disease symptoms.

1 - Up to 10 per cent leaf / stem / inflorescence/ fruit area infected

2 - 11-25 per cent leaf / stem / fruit area infected

3 - 26-50 per cent leaf / stem / fruit area infected

4 - More than 50 per cent leaf / stem / fruit area infected

\section{5 - Complete drying of leaf / stem / fruit}

Further, the scale was converted into severity (Per cent Disease Index i.e. PDI) using the formula given by Wheeler (1969).

PDI $=($ Sum of numerical rating $/$ Total number of leaves examined) $\times$ (Maximum grade value / 100) 
Phyto-toxicty observation on $0-10$ scale for leaf tips and surface injury, wilting, necrosis, epinasty and hyponasty. Three plants were selected at random from each treatment and the total number of leaves and those showing phyto-toxicty were counted. The data collected were converted in to percentage. The extent of phyto-toxicty is recorded based on scores given in Table 1.

\section{Results and Discussion}

\section{Efficacy of fungicide on per cent disease index (PDI)}

The two years pooled data of 2012-13 and 2013-14 on per cent disease index (PDI) on leaves, inflorescence and fruits as influenced by different fungicides against powdery mildew is presented in Table 2, 3 and 4, respectively.

The result presented in Table 2 revealed that, all the fungicidal treatments were found effective in reducing the disease index of Powdery Mildew in mango over control. Among the different treatments, pre-mix fungicide, Fluxapyroxad 250g/l + Pyraclostrobin 250g/l @ $2 \mathrm{ml} / \mathrm{l}$ recorded significantly lower PDI (18.00) on leaves resulted 68.63 per cent reduction in PDI over control (Table 2).

The PDI on inflorescence was also found minimum in Fluxapyroxad 250g/l + Pyraclostrobin 250g/l @ $2 \mathrm{ml} / \mathrm{l}$ followed by Fluxapyroxad @ 3ml/l (Table 3). This is mainly due to fluxapyroxad shows broad spectrum of activity and is announced to be a mixing partner for epoxiconazole and pyraclostrobin to be used in many crops including fruits, vegetables and cereals (Semar et al., 2011; Walter, 2010). The compound provides preventive, curative and long lasting efficacy and is expected to have significant sales potential and the market introduction in 2012.

Though the traditional old chemical hexaconazole significantly reduced the disease incidence on leaves, fruits and inflorescence over control, new generation chemicals pyraclostrobin and fluxapyroxad were more efficient.

Because pyraclostrobin belongs to the strobilurins group, is the leading systemic fungicide, found to exert their fungicidal action by blocking electron transport in the mitochondrial respiratory chain in fungi (Gerth et al., 1980).

Among the different treatments, Fluxapyroxad 250g/l +Pyraclostrobin 250g/l 500 SC @ 2ml/1 also recorded significantly lower per cent disease index of powdery mildew on fruits (17.08) than control (53.33).

The pre-mixture fungicides were found highly effective in controlling the powdery mildew disease when compared to the individual fungicide spray separately (Table 4). Karaoglanidisa and Karadimosb (2006) reported that efficacy of strobilurins increased when mixed with other broad spectrum or contact fungicides in controlling powdery mildew in field-grown sugar beet.

They provided better control efficacy compared to single applications of traditional or strobilurin fungicides. As the concentration of pre-mix fungicide Fluxapyroxad 250g/l +Pyraclostrobin 250g/l 500 SC increased, the PDI on leaves, fruits and inflorescence also reduced. This might be due to the extent of inhibition of sporangial germination increased with the increase in concentration of fungicides. 
Table.1 Phyto-toxicty observations on 0 -10 scale

\begin{tabular}{|c|c|}
\hline \multicolumn{2}{|c|}{ Scale } \\
\hline Per centage & Grade \\
\hline $0-10 \%$ & 1 \\
\hline $11-20 \%$ & 2 \\
\hline $21-30 \%$ & 3 \\
\hline $31-40 \%$ & 4 \\
\hline $41-50 \%$ & 5 \\
\hline $51-60 \%$ & 6 \\
\hline $61-70 \%$ & 7 \\
\hline $71-80 \%$ & 8 \\
\hline $81-90 \%$ & 9 \\
\hline $91-100 \%$ & 10 \\
\hline
\end{tabular}

Table.2 Per cent Disease Index (PDI) on leaves as influenced by different plant protection fungicides against powdery mildew disease of mango

\begin{tabular}{|c|c|c|c|c|c|}
\hline \multirow{2}{*}{$\begin{array}{l}\text { Sl. } \\
\text { No }\end{array}$} & \multirow[t]{2}{*}{ Treatment } & \multicolumn{3}{|c|}{ PDI on Leaves } & \multirow{2}{*}{$\begin{array}{c}\% \\
\text { Reduction } \\
\text { Over } \\
\text { control } \\
\end{array}$} \\
\hline & & 2012-13 & 2013-14 & Pooled & \\
\hline $\mathbf{T}_{1}$ & $\begin{array}{l}\text { Fluxapyroxad 250g/1 } \\
\text { +Pyraclostrobin 250g/1 } 500 \\
\text { SC @ 1ml/1 }\end{array}$ & $22.45(28.25)$ & $20.30(26.78)$ & $21.38(27.54)$ & 62.09 \\
\hline $\mathbf{T}_{2}$ & $\begin{array}{l}\text { Fluxapyroxad } 250 \mathrm{~g} / \mathrm{l} \\
\text { +Pyraclostrobin } 250 \mathrm{~g} / 1500 \\
\text { SC @ } 1.5 \mathrm{ml} / 1\end{array}$ & $21.00(22.28)$ & $18.50(25.47)$ & $19.75(26.38)$ & 65.45 \\
\hline$\overline{T_{3}}$ & $\begin{array}{l}\text { Fluxapyroxad 250g/l } \\
\text { +Pyraclostrobin 250g/l } 500 \\
\text { SC @ } 2 \mathrm{ml} / 1\end{array}$ & $19.20(25.84)$ & $16.80(24.19)$ & $18.00(25.10)$ & 68.63 \\
\hline $\mathbf{T}_{4}$ & $\begin{array}{l}\text { Pyraclostrobin 20WG @ } \\
5 \mathrm{ml} / 1\end{array}$ & $20.10(26.64)$ & $19.85(26.45)$ & $19.98(26.54)$ & 62.93 \\
\hline $\mathbf{T}_{5}$ & Fluxapyroxad@3ml/1 & $19.80(20.09)$ & $18.90(25.77)$ & 19.35 (26.09) & 64.71 \\
\hline $\mathrm{T}_{6}$ & $\begin{array}{l}\text { Flusilazole } 40 \% \text { EC @ } \\
0.75 \mathrm{ml} / 1\end{array}$ & $23.65(29.06)$ & $21.50(27.62)$ & $22.58(28.37)$ & 59.85 \\
\hline $\mathbf{T}_{7}$ & $\begin{array}{l}\text { Hexaconazole 5\% SC @ } \\
2 \mathrm{ml} / 1\end{array}$ & $24.70(29.80)$ & $22.80(28.52)$ & $23.75(29.16)$ & 57.42 \\
\hline $\mathbf{T}_{8}$ & Control & $55.90(48.39)$ & $53.55(47.03)$ & $54.73(47.71)$ & \\
\hline & SEm \pm & 0.28 & 0.61 & 0.23 & \\
\hline & CD@5\% & 0.83 & 1.86 & 0.71 & \\
\hline
\end{tabular}

Figures in parenthesis indicate arcsine values. 
Table.3 Per cent Disease Index (PDI) on inflorescence as influenced by different plant protection fungicides against Powdery Mildew Disease of Mango.

\begin{tabular}{|c|c|c|c|c|c|}
\hline \multirow[t]{2}{*}{ SI. No } & \multirow[t]{2}{*}{ Treatment } & \multicolumn{3}{|c|}{ PDI on Inflorescence } & \multirow{2}{*}{$\begin{array}{l}\text { \% Reduction } \\
\text { Over control }\end{array}$} \\
\hline & & $2012-13$ & 2013-14 & Pooled & \\
\hline$\overline{T_{1}}$ & $\begin{array}{l}\text { Fluxapyroxad } 250 \mathrm{~g} / 1 \\
\text { +Pyraclostrobin } 250 \mathrm{~g} / 1500 \\
\text { SC @ } 1 \mathrm{ml} / 1\end{array}$ & $21.20(27.42)$ & $19.50(26.20)$ & $20.35(26.81)$ & 62.36 \\
\hline$\overline{T_{2}}$ & $\begin{array}{l}\text { Fluxapyroxad } 250 \mathrm{~g} / \mathrm{l} \\
\text { +Pyraclostrobin } 250 \mathrm{~g} / 1500 \\
\text { SC @ } 1.5 \mathrm{ml} / 1\end{array}$ & $20.60(26.99)$ & $17.25(24.54)$ & $18.93(25.78)$ & 66.70 \\
\hline$\overline{\mathrm{T}_{3}}$ & $\begin{array}{l}\text { Fluxapyroxad } 250 \mathrm{~g} / \mathrm{l} \\
\text { +Pyraclostrobin } 250 \mathrm{~g} / \mathrm{l} 500 \\
\mathrm{SC} @ 2 \mathrm{ml} / 1\end{array}$ & $17.60(24.80)$ & $15.60(23.26)$ & $16.60(24.04)$ & 69.88 \\
\hline $\mathbf{T}_{4}$ & $\begin{array}{l}\text { Pyraclostrobin } 20 \text { WG @ } \\
5 \mathrm{ml} / 1\end{array}$ & $19.40(26.13)$ & $18.25(25.29)$ & $18.83(25.71)$ & 64.77 \\
\hline$\overline{T_{5}}$ & Fluxapyroxad@3ml/1 & $17.80(24.95)$ & $16.50(23.96)$ & $17.15(24.46)$ & 68.15 \\
\hline $\mathrm{T}_{6}$ & $\begin{array}{l}\text { Flusilazole } 40 \% \text { EC @ } \\
0.75 \mathrm{ml} / 1\end{array}$ & $20.30(26.78)$ & $19.90(26.49)$ & $20.10(26.63)$ & 61.58 \\
\hline $\mathbf{T}_{7}$ & $\begin{array}{l}\text { Hexaconazole 5\% SC @ } \\
2 \mathrm{ml} / 1\end{array}$ & $24.30(29.53)$ & $22.50(28.31)$ & $23.40(28.93)$ & 56.56 \\
\hline $\mathbf{T}_{8}$ & Control & $53.80(47.18)$ & $51.80(46.03)$ & $52.80(46.60)$ & \\
\hline & SEm \pm & 0.09 & 0.20 & 0.25 & \\
\hline & CD@5\% & 0.28 & 0.62 & 0.74 & \\
\hline
\end{tabular}

Figures in parenthesis indicate arcsine values.

Table.4 Per cent Disease Index (PDI) on fruits as influenced by different plant protection fungicides against powdery mildew disease of mango

\begin{tabular}{|c|c|c|c|c|c|}
\hline \multirow[t]{2}{*}{ Sl. No } & \multirow[t]{2}{*}{ Treatment } & \multicolumn{3}{|c|}{ PDI on Fruits } & \multirow{2}{*}{$\begin{array}{l}\text { \% Reduction } \\
\text { Over control }\end{array}$} \\
\hline & & $2012-13$ & 2013-14 & Pooled & \\
\hline $\mathrm{T}_{1}$ & $\begin{array}{l}\text { Fluxapyroxad } 250 \mathrm{~g} / \mathrm{l} \\
+ \text { +Pyraclostrobin } 250 \mathrm{~g} / 1500 \\
\mathrm{SC} @ 1 \mathrm{ml} / 1\end{array}$ & $22.10(28.11)$ & $21.00(27.27)$ & $21.55(27.66)$ & 59.81 \\
\hline$\overline{T_{2}}$ & $\begin{array}{l}\text { Fluxapyroxad } 250 \mathrm{~g} / \mathrm{l} \\
\text { +Pyraclostrobin } 250 \mathrm{~g} / 1500 \\
\mathrm{SC} @ 1.5 \mathrm{ml} / 1\end{array}$ & $20.30(26.78)$ & $17.80(24.95)$ & $19.05(25.88)$ & 65.93 \\
\hline$\overline{T_{3}}$ & $\begin{array}{l}\text { Fluxapyroxad } 250 \mathrm{~g} / \mathrm{l} \\
\text { +Pyraclostrobin } 250 \mathrm{~g} / 1500 \\
\text { SC @ } 2 \mathrm{ml} / 1\end{array}$ & $18.60(25.55)$ & $15.55(23.22)$ & $17.08(24.40)$ & 70.24 \\
\hline $\mathbf{T}_{4}$ & $\begin{array}{l}\text { Pyraclostrobin } 20 \text { WG @ } \\
5 \mathrm{ml} / 1\end{array}$ & $19.50(26.21)$ & $19.40(26.13)$ & $19.45(26.17)$ & 62.87 \\
\hline $\mathbf{T}_{5}$ & Fluxapyroxad @ 3ml/1 & $19.80(26.42)$ & $21.00(27.27)$ & $20.40(26.85)$ & 59.81 \\
\hline $\mathbf{T}_{6}$ & $\begin{array}{l}\text { Flusilazole } 40 \text { \% EC @ } \\
0.75 \mathrm{ml} / 1\end{array}$ & $21.50(27.69)$ & $21.40(27.62)$ & $21.50(27.62)$ & 59.04 \\
\hline $\mathbf{T}_{7}$ & $\begin{array}{l}\text { Hexaconazole 5\% SC @ } \\
2 \mathrm{ml} / 1\end{array}$ & $24.30(29.53)$ & $21.90(27.90)$ & $23.10(28.72)$ & 58.09 \\
\hline $\mathbf{T}_{8}$ & Control & $54.40(47.52)$ & $52.25(46.28)$ & $53.33(46.90)$ & \\
\hline & SEm \pm & 0.26 & 0.62 & 0.43 & \\
\hline & CD@5\% & 0.78 & 1.87 & 1.32 & \\
\hline
\end{tabular}

Figures in parenthesis indicate arcsine values. 
Table.5 Phyto-toxicty report of Fluxapyroxad 250g/1 +Pyraclostrobin 250g/1 500 SC on mango at different intervals of time after spraying

\begin{tabular}{|c|c|c|c|c|c|c|}
\hline \multirow{2}{*}{$\begin{array}{c}\text { Day of } \\
\text { observation after } \\
\text { each spray }\end{array}$} & \multirow[b]{2}{*}{ Treatments } & \multicolumn{5}{|c|}{ Phyto-toxicty Symptoms } \\
\hline & & $\begin{array}{l}\text { Leaf tips and } \\
\text { surface injury }\end{array}$ & Wilting & $\begin{array}{c}\text { Vein } \\
\text { clearing }\end{array}$ & Necrosis & $\begin{array}{l}\text { Epinasty and } \\
\text { hyponasty }\end{array}$ \\
\hline $1^{\text {st }}$ Day & $\begin{array}{lr}\text { Recommended dose }-\mathrm{X} \\
-2 \mathrm{X} \\
-4 \mathrm{X} \\
\text { Untreated control }\end{array}$ & $\begin{array}{l}0 \\
0 \\
0 \\
0\end{array}$ & $\begin{array}{l}0 \\
0 \\
0 \\
0\end{array}$ & $\begin{array}{l}0 \\
0 \\
0 \\
0\end{array}$ & $\begin{array}{l}0 \\
0 \\
0 \\
0\end{array}$ & $\begin{array}{l}\mathbf{0} \\
\mathbf{0} \\
\mathbf{0} \\
\mathbf{0}\end{array}$ \\
\hline $3^{\text {rd }}$ Day & $\begin{array}{lr}\text { Recommended dose }-\mathrm{X} \\
-2 \mathrm{X} \\
-4 \mathrm{X}\end{array}$ & $\begin{array}{l}0 \\
0 \\
0 \\
0\end{array}$ & $\begin{array}{l}0 \\
0 \\
0 \\
0\end{array}$ & $\begin{array}{l}0 \\
0 \\
0 \\
0\end{array}$ & $\begin{array}{l}0 \\
0 \\
0 \\
0\end{array}$ & $\begin{array}{l}0 \\
0 \\
0 \\
0 \\
0\end{array}$ \\
\hline $5^{\text {th }}$ Day & $\begin{array}{l}\begin{array}{l}\text { Recommended dose }-\mathrm{X} \\
-2 \mathrm{X} \\
-4 \mathrm{X}\end{array} \\
\begin{array}{l}\text { Untreated control } \\
\end{array}\end{array}$ & $\begin{array}{l}0 \\
0 \\
0 \\
0\end{array}$ & $\begin{array}{l}0 \\
0 \\
0 \\
0\end{array}$ & $\begin{array}{l}0 \\
0 \\
0 \\
0\end{array}$ & $\begin{array}{l}0 \\
0 \\
0 \\
0\end{array}$ & $\begin{array}{l}\mathbf{0} \\
\mathbf{0} \\
\mathbf{0} \\
\mathbf{0}\end{array}$ \\
\hline $7^{\text {th }}$ Day & $\begin{array}{ll}\text { Recommended dose }-\mathrm{X} \\
-2 \mathrm{X} \\
-4 \mathrm{X}\end{array}$ & $\begin{array}{l}0 \\
0 \\
0 \\
0\end{array}$ & $\begin{array}{l}0 \\
0 \\
0 \\
0\end{array}$ & $\begin{array}{l}0 \\
0 \\
0 \\
0\end{array}$ & $\begin{array}{l}0 \\
0 \\
0 \\
0\end{array}$ & $\begin{array}{l}\mathbf{0} \\
\mathbf{0} \\
\mathbf{0} \\
\mathbf{0}\end{array}$ \\
\hline $10^{\text {th }}$ Day & $\begin{array}{l}\begin{array}{l}\text { Recommended dose }-\mathrm{X} \\
-2 \mathrm{X} \\
-4 \mathrm{X}\end{array} \\
\text { Untreated control }\end{array}$ & $\begin{array}{l}0 \\
0 \\
0 \\
0\end{array}$ & $\begin{array}{l}\mathbf{0} \\
\mathbf{0} \\
\mathbf{0} \\
\mathbf{0}\end{array}$ & $\begin{array}{l}\mathbf{0} \\
\mathbf{0} \\
\mathbf{0} \\
\mathbf{0}\end{array}$ & $\begin{array}{l}\mathbf{0} \\
\mathbf{0} \\
\mathbf{0} \\
\mathbf{0}\end{array}$ & $\begin{array}{l}0 \\
0 \\
0 \\
0\end{array}$ \\
\hline
\end{tabular}

Score: $0=$ No Phytotoxicity $100=100 \%$ Phytotoxicity

Fig.1 Influence of different plant protection fungicides on productivity of Mango

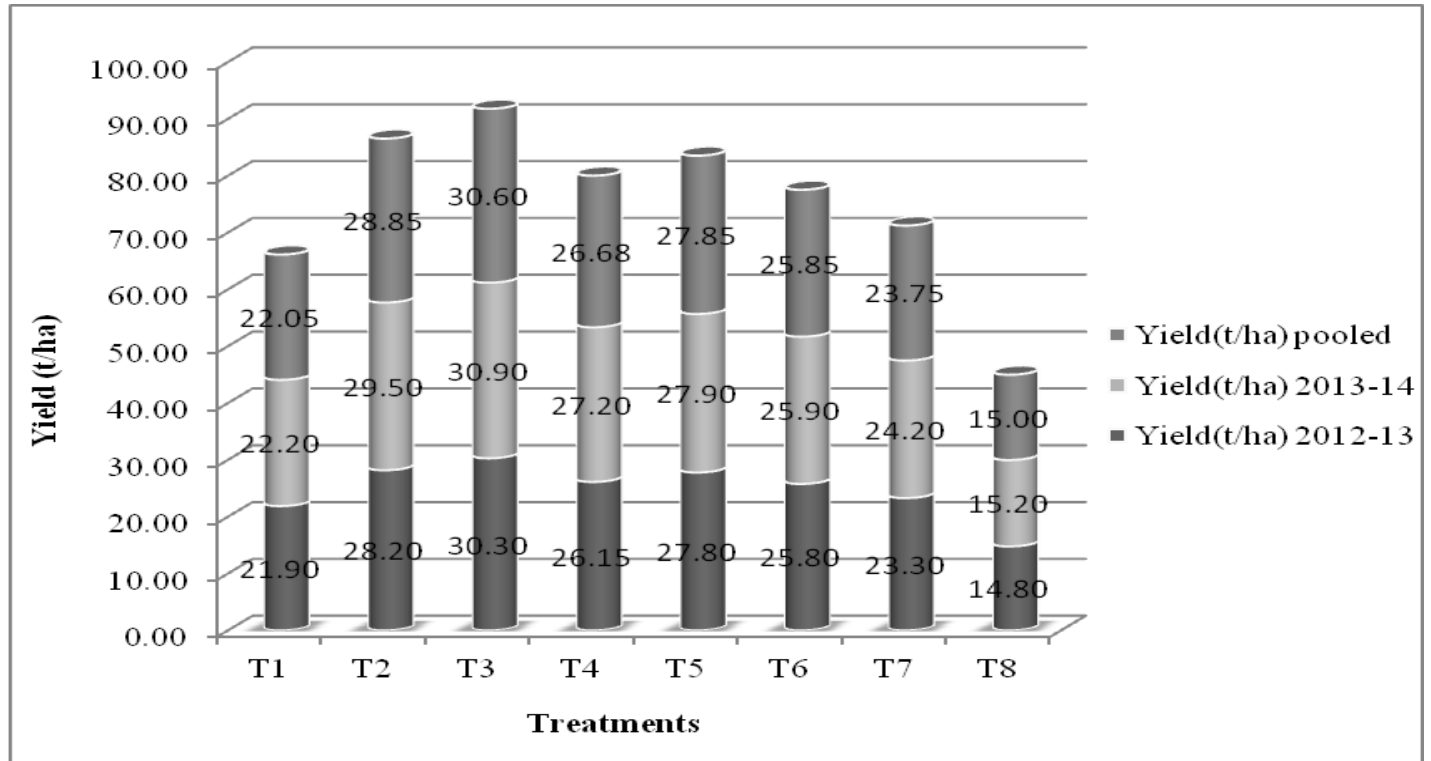

Where, $\mathrm{T}_{1}$ : Fluxapyroxad 250g/l +Pyraclostrobin 250g/l $500 \mathrm{SC} @ 1 \mathrm{ml} / \mathrm{L}$;

$\mathrm{T}_{2}$ : Fluxapyroxad 250g/l +Pyraclostrobin 250g/1 $500 \mathrm{SC} @ 1.5 \mathrm{ml} / \mathrm{L}$;

$\mathrm{T}_{3}$ : Fluxapyroxad 250g/l +Pyraclostrobin 250g/1 $500 \mathrm{SC} @ 2 \mathrm{ml} / \mathrm{L}$;

$\mathrm{T}_{4}$ : Pyraclostrobin $20 \mathrm{WG} @$ 5ml/L; $\mathrm{T}_{5}$ : Fluxapyroxad @ 3ml/L; $\mathrm{T}_{6}$ : Flusilazole $40 \% \mathrm{EC} @ 0.75 \mathrm{ml} / \mathrm{L}$;

$\mathrm{T}_{7}$ : Hexaconazole 5\% SC @ 2ml/L; $\mathrm{T}_{8}$ : Control 


\section{Influence of pre-mixture fungicide on yield}

The productivity of mango was recorded maximum (30.60 t/ha) in Fluxapyroxad 250g/l +Pyraclostrobin 250g/l $500 \mathrm{SC}$ at $2 \mathrm{ml} / \mathrm{l}$ followed by $1.5 \mathrm{ml} / \mathrm{l}$ concentration (Fig. 1). The yield was significantly low in untreated control $(15.00 \mathrm{t} / \mathrm{ha})$. All fungicides significantly increased the yield as compared to untreated control. It has both excellent preventative and curative activity through the inhibition of fungi at several stages of the fungal lifecycle including spore germination, germ tube growth, appresoria formation and mycelial growth (Strathmann et al., 2011). Overall, Fluxapyroxad 250g/l + Pyraclostrobin 250g/l 500 SC @ 2ml/1 was found to be the best treatment for controlling powdery mildew disease in mango. It also resulted in 104 per cent increase in yield over untreated control.

Adaskaveg (2011) found that the new SDHI products, fluopyram and fluxapyroxad, are highly effective against powdery mildew but will only be sold as premixtures. Thus the premixtures offer high activity, very consistent performance, and built-in resistance management with two different modes of action for powdery mildew management.

Though the Pyraclostrobin and fluxapyraxad sprayed separately were found effective in control of powdery mildew disease, there were lots of research findings, where they develop resistance very quickly and their efficacy declined dramatically after the second application.

Initially they could able to reduce $96-98$ percent of disease incidence, repeated sprays fail to control the disease even at low disease pressure in grapes and cucumber (Kast and Bleyer, 2011; McGrath and Shishkoff, 2003). Hence the premixture fungicides were found to be more effective for controlling the powdery mildew in stone fruits and are the best solution to overcome the resistance development (Schilder, 2015).

\section{Phyto-toxicty}

The result of phyto-toxicty studies of Fluxapyroxad 250g/l +Pyraclostrobin 250g/l $500 \mathrm{SC}$ is presented in Table 5. The observations on the leaf tip, surface injury, wilting, vein clearing, necrosis, epinasty, hyponasty and fruit injury were recorded during both the seasons and there were no visual symptoms of phyto-toxicty noticed on mango. There were no visual symptoms of phytotoxicty noticed in terms of leaf tips and surface injury, wilting, necrosis, epinasty and hyponasty on mango crop by Fluxapyroxad 250g/l + Pyraclostrobin 250g/l $500 \mathrm{SC}$ treatment even at 4ml/l concentration. Strathmann et al., (2011), demonstrated fluxapyroxad is highly active on several major plant pathogens from the Ascomycete, Basidiomycete, Deuteromycete and Zygomycete classes of fungi. It was found to be effective for use on a wide variety of crops, including cereals, corn, soybean, fruiting vegetables, tuberous and corm vegetables, pome fruits and stone fruits with excellent crop safety.

However, the Fungicide Resistance Action Committee has developed resistance management recommendations for pathogens of different crops in order to reduce the risk for resistance development to this class of fungicides (FRAC, 2013). These recommendations include preventative usage, mixture with partner fungicides active against the current pathogen population, alternation in the mode of action of products used in a spray program, and limitations in the total number of applications per season or per crop (Sierotzki and Scalliet, 2013). Findings of our field studies suggest that Fluxapyroxad 250g/1 + Pyraclostrobin 250g/l $500 \mathrm{SC}$ is effective in reducing powdery mildew on leaves, flowers and fruits at $2 \mathrm{ml} / 1$ concentrations. No phytotoxic symptoms were recorded after spraying on the plants even at higher dose.

The application of Fluxapyroxad 250g/l + Pyraclostrobin 250g/l 500 SC has significantly decreased the powdery mildew diseases and at the same time it increased the productivity in 
mango. Fluxapyroxad 250g/l + Pyraclostrobin $250 \mathrm{~g} / \mathrm{l} 500 \mathrm{SC}$ at the standard dose $(2 \mathrm{ml} / 1$ concentration) tested was found effective and superior to other fungicides evaluated together.

\section{References}

Adaskaveg, J.E. 2011. Managing powdery mildew in peach orchards. UC Riverside Orchard Notes. http://www.westernfarmpress.com/orchar d-crops/managing-powdery-mildewpeach-orchards.

FRAC (Fungicide Resistance Action Committee), 2013. URL http://www.frac.info/

Gerth, K., Irschik, H., Reichenbach, H. and Trowitzsch, W. 1980. Myxothiazol, an antibiotic from Myxococcus fulvus (Myxobacterales) - Cultivation, isolation, physicochemical and biological properties. Journal of Antibiotics. 33:1474-1479.

Karaoglanidisa, G.S. and Karadimosb, D.A. 2006. Efficacy of strobilurins and mixtures with DMI fungicides in controlling powdery mildew in fieldgrown sugar beet. Crop Protection, 25: 977-983.

Kast, W.K. and Bleyer, K. 2011. Efficacy of sprays applied against powdery mildew (Erysiphe necator) during a critical period for infections of clusters of grapevines (Vitis vinifera). Journal of Plant Pathology, 93(1): 29-32.

Khalid, P.A. and Alam, S.S. 2000. Powdery Mildew of Mango: A Review. Pakistan Journal of Biological Sciences, 3(7): 1119-1122.

Margot, P., Huggenberger, F., Amrein, J. and Weiss, B. 1998. CGA 279202: a new broad-spectrum strobilurin fungicide. In:
The Proceedings of the Brighton Crop Protection Conference. Farnham, UK: British Crop Protection Council, pp- 375382.

McGrath, M.T. and Shishkoff, N. 2003. First Report of the Cucurbit Powdery Mildew Fungus (Podosphaera xanthii) Resistant to Strobilurin Fungicides in the United States. Plant Disease, 87(8): 1007

Nelson, S.C. 2008. Mango powdery mildew. Version: August 2008. URL https://www.ctahr.hawaii.edu/oc/freepubs /pdf/PD-46.pdf.

Schilder, A. 2015. Merivon, a new fungicide option for disease control in strawberries. Michigan State University Extension Bulletin, http://tinyurl.com/ y8fxgv3m.

Semar, M., Strobel, D., Strathmann, S. and Groeger, U. 2011. Xemium: The BASF fungicide innovation. In: Modern Fungicides and Antifungal Compounds VI, H.W. Dehne, H.B. Deising, U. Gisi, K.H. Kuck, P.E. Russell and H. Lyr (Eds). DPG-Verlag, Braunschweig, Germany, pp- 63-68.

Sierotzki, H. and Scalliet, G. 2013. A review of current knowledge of resistance aspects for the next-generation succinate dehydrogenase inhibitor fungicides. Phytopathology, 103(9): 880-887.

Strathmann, S., Walker, S. and Barnes, J. 2011. Fluxapyroxad: A new broad-spectrum fungicide. Phytopathology, 101(6): 172.

Walter, H. 2010. New Fungicides and New Modes of Action. In: Modern Fungicides and Antifungal Compounds VI, H.W. Dehne, H.B. Deising, U. Gisi, K.H. Kuck, P.E. Russell and H. Lyr (Eds). Friedrichroda, Germany. Pp. 47-54.

Wheeler, B. E. J. 1969. An introduction to plant diseases. John Wiley and Sons Ltd., London. Pp. 301.

\section{How to cite this article:}

Ravikumar, M.R., Vithal Navi and Yashaswini Sharma. 2018. Evaluation of Pre-Mix Fungicide, Fluxapyroxad and Pyraclostrobin 500 SC against Powdery Mildew (Oidium mangiferae) Disease of Mango. Int.J.Curr.Microbiol.App.Sci. 7(01): 439-446.

doi: https://doi.org/10.20546/ijcmas.2018.701.051 